\title{
MENGANALISIS PATOLOGI MEDIA SOSIAL DARI PERSPEKTIF FILSAFAT POSTMODERNISME
}

\author{
Fabianus Fensi ${ }^{1}$ \\ ${ }^{1}$ Program Studi Ilmu Komunikasi \\ Universitas Bunda Mulia \\ Surel: fabianusfensi@gmail.com
}

Diterima : 09 Januari 2020; Review : 06 Februari 2020; Direvisi Author : 09 Februari 2020; Terbit : 14 Februari 2020

\begin{abstract}
Social media in the entire history of its birth cannot be separated from the history of modernity. He is no longer just a phenomenon of lifestyle but also the user's self-statement as an autonomous subject. The existence of social media, on the one hand greets the world with all its hospitality, but on the other hand, it becomes a tool of social terror for the community. Both of these are called pathology. Social media adopted the workings of modernity to illustrate its existence. By using the postmodern approach, this research seeks to reveal the pathology of social media. The postmodern approach is used to provide opportunities for the operation of traditional ethical values in the form of, for example, protecting everyone's privacy, ensuring the accuracy of information, protecting everyone's human rights, ensuring everyone to access various available resources, and freedom of expression must always consider social plurality with various small narratives accompanying it. Social media as a marker of modernity does not always oppose with various ethical considerations, but always moves together to build a constructive civilization. Postmodernism, not only offers a progression approach, but also the way regression works, namely returning to traditional ethics.
\end{abstract}

Keywords: Social Media, Modernity, Pathology, Postmodernity.

\section{PENDAHULUAN}

Kita memaklumi bahwa perkembangan dan penggunaan media sosial (Facebook, Instagram, Twitter, Youtube, Wikipedia, MySpace, dan blogs), dewasa ini tidak lagi sekadar mode yang menandai modernitas sosial, di mana hampir seluruh aspek kehidupan manusia dimudahkan olehnya, atau momentum di mana segala sesuatu, termasuk gaya hidup, diukurkan dari dan kepadanya. Lebih dari semuanya, media sosial dan siapapun yang menggunakannya, sedang menggiring kita kepada pewartaan paling mutlak atas jati diri sebagai subyek otonom. Dan, inilah kenyataan yang paling dibanggakan oleh berbagai pemikiran dan cara kerja modernitas.

Manusia menjadi ukuran segala sesuatu. Proyek filsafat rasionalisme Rene Descartes (1596-1650) menandai afirmasi diri ini. "Cogito Ergo Sum" (saya berpikir maka saya ada) adalah kalimat berpengaruh Descartes untuk mengungkapkan peranan penting kegiatan berpikir sebagai bagian yang tidak terpisahkan dari eksistensi manusia. Tidak mengherankan, kalau kemudian hasil kegiatan berpikir diarahkan kepada penciptaan 
teknis berbagai produk dan saranan modernitas.

Sebagai salah satu bagian dari perkembangan teknis, teknologi modern media sosial membawa dalam dirinya dua wajah sekaligus, yang satu wajah ramah karena mampu menyapa dunia dengan segala problematikanya, satu lainnya, wajah menakutkan, karena sering dipakai sebagai alat provokasi, bahkan membawa teror (sosial, budaya, politik, etika) bagi kehidupan masyarakat. Bagaimana pun tingkat pemakaian media sosial, facebook misalnya, selalu diikuti kerugian sosial, yang saya sebut sebagai patologi etis, bagi kehidupan bersama masyarakat.

Penelitian ini berkonsentrasi pada wajah kedua, yang saya namakan sebagai wajah penuh patologi yang darinya banyak kerenggangan jarak sosial, baik antarindividu maupun antarkelompok orang terjadi; banyak kecurigaan orang atau kelompok orang terjadi karena media sosial memberi ruang pertarungan pesan tanpa bereferensi apapun pada standar etis masyarakat. Masyarakat yang seharusnya mencintai perdamaian, media sosial menjelmakan dirinya sebagai monster penyebar teror dalam masyarakat yang secara sengaja didisain untuk bertarung satu sama lain.

Sebagai produk modernitas, media sosial, sejatinya sebagai medium pertemuan wajah dialogis, a la Martin Buber (18781965), tetapi wajah lewiathan a la Thomas
E-ISSN. 2615.6725

Hobbes (1588-1679) pun tidak bisa dihindarkan. Idealisme media sosial, sebagai medium perjumpaan sosial tanpa batas a la Marshall McLuhan (1911-80), mengandung dalam dirinya kenyataan yang sebaliknya. Patologi ini akan ditelusuri dengan menggunakan perspektif postmodernisme sehingga paradoks etis yang dikandung media sosial dapat terungkap.

\section{METODOLOGI PENELITIAN}

Penelitian ini adalah sebuah penelitian kualitatif berbasis kajian-kajian literatur. Objek kajiannya adalah media sosial.Kita semua tahu bahwa penelitian kualitatif merupakan sebuah metode yang bersifat eksploratif dan berusaha memahami sebuah makna, yang oleh sejumlah individu atau sekelompok orang, dianggap berasal dari masalah sosial kemanusiaan (Creswell, 2010: 4).

Subjektivitas penelitian ini sangat tinggi karena berdasarkan pembacaan atas berbagai literatur peneliti berusaha menganalisis fenomena media sosial yang ada dengan bantuan cara berpikir postmodenrisme. Kita tahu bahwa penelitian-penelitian kualitatif selalu bersifat subyektif. Dia mendasarkan diri pada asumsi bahwa pengetahuan tidak mempunyai sifat yang obyektif dan tetap, atau universal, tetapi bersifat interpretif.

Perilaku manusia selalu berkembang berdasarkan konteks sosial tertentu. Perilaku manusia dengan demikian pun terbentuk 
karena makna yang mereka konstruksikan atas lingkungan sosial dimana mereka hidup. Dedy Mulyana (2013: 32-38) mengatakan bahwa realitas sosial bersifat begitu cair dan dengan mudah berubah melalui interaksi. Berbagai fenomena sosial selalu bersifat sementara dan memiliki makna yang plural. Dan, di sini selalu diandaikan terjadi negosiasi untuk menetapkan status dari realitas yang sedang dihadapi tersebut.

Postmodernisme adalah salah satu pendekatan subjektif yang memiliki tekad membongkar kepalsuan modernitas. Penelitian ini menggunakan pendekatan postmodernisme untuk menunjukkan kepalsuan modernitas, yang oleh peneliti menyebutnya sebagai patologi. Dengan demikian, dapat dikatakan bahwa dengan menggunakan paradigma postmodernisme, penelitian ini memiliki dua maksud, yaitu: di satu pihak mau mengungkapkan patologi yang dikandung oleh modernitas media sosial, dan di lain pihak,penelitian ini berusaha merumuskan jalan tengah etis untuk mengatasi patologi dan kepalsuan modernitas media sosial tersebut.

\section{HASIL DAN PEMBAHASAN}

\section{Filsafat Postmodernisme sebagai Fenomena}

\section{Sejarah}

Tidak mungkin memahami postmodernisme tanpa memahami hubungan, bahkan oposisinya dengan modernisme. Stephen R. C. Hicks $(2014$, i) membuat sebuah tesis menarik bahwa kegagalan epistemologi memungkinkan postmodernisme, dan kegagalan sosialisme membuat postmodernisme menjadi penting.

Dengan tesis ini sebenarnya mau dikatakan bahwa postmodernisme, tidak sekadar cara berpikir dan pengetahuan sosial tentang masyarakat dan kebudayaan tetapi juga sebuah gerakan tentang masyarakat, kebudayaan, dan perkembangan dari keduanya dalam sejarah. Atau, postmodernisme adalah strategi melawan koalisi antara argumentasi rasional dengan kekuasaan (Stephen R. C. Hicks, 2014, 3).

Mengutip Frank Lentricchia, Stephen R. C. Hicks, mengatakan bahwa postmodernisme berusaha mencari, tidak untuk mendapatkan dasar dan syarat sebuah kebenaran pengetahuan, tetapi mencari praktik kekuasaan untuk tujuan perubahan sosial. Namun, yang pasti bahwa postmodernisme menolak proyek pencerahan yang didasari berbagai premis modernitas. Di satu sisi, menurut Stephen R. C. Hicks, ketika dunia modern berbicara argumentasi rasional, kebebasan, dan perkembangan, sebenarnya dia sedang berceritera tentang patologi dari ketiganya.

Postmodernisme dengan demikian mengeritik patologi rasional, kebebasan, dan perkembangan tersebut sebagai pratanda lonceng kematian modernitas sedang berdering. Postmodern menolak proyek pencerahan, menyerang tema esensial yang menyertainya, menolak berbagai alasan rasional dan individualisme, di mana berbagai pandangan pencerahan terletak di atasnya. 
Singkatnya potsmodernisme merupakan oposisi kritis dari modernisme.

Kalau modernisme memerdebatkan kebenaran, argumentasi rasional, pengalaman, kebebasan dan kesetaraan, keadilan dan perdamaian, dan kemajuan, maka kerangka berpikir postmodernisme meletakkan konsepkonsep tersebut dalam sebuah rimbah raya serba pertanyaan.

Menurut pandangan postmodernisme, obyektivitas adalah mitos, tidak ada kebenaran, tidak ada cara obyektif untuk memahami alam atau sebuah teks. Segala bentuk tafsir diterima sebagai kesetaraan yang valid. Segala bentuk nilai adalah produk dari subyektivitas sosial. Secara kultural, nilai kelompok tidak berdiri sendiri, tetapi dipengaruhi oleh pluralitas konteks sosial (Stephen R. C. Hicks, 2014, 20).

Jean-Francois Lyotard (1924-98), mengatakan bahwa postmodernisme adalah pertarungan antara little narratives vs grand narrative. Liitle narratives menjadi begitu menonjol ketika grand narrative yang dibawa oleh modernitas kehilangan kredibilitasnya. Modernitas menyiapkan isu dalam konteks global, namun dia mengabaikan isu lokal sebagai little narratives. Postmodern memberi ruang kepada narasi-narasi kecil, atau postmodern menandai mati grand narrative modernitas dengan munculnya berbagai alternatif pengganti dalam ceritera-ceritera kecil konteks budaya dan beragamnya sistem nilai (Victor E. Taylor \& Charles E. Winquist, 2001: 234-235).

Postmodernisme (Liliweri, 2018) dipandang sebagai seruan kematian bagi semua penyelidikan ilmiah, atau kiamat bagi semua pengetahuan baru, atau rontoknya pengetahuan standar dalam menilai sebuah teori, dan pemalingan arah ke relativisme. Beberapa keyakinan dasar postmodernisme: pengetahuan terfragmentasi; kenyataan itu kontradiktif; pengalaman estetika lebih penting dari persepsi sensorik; kemajuan sains itu mitos; semua pengetahuan ilmiah harus didekonstruksikan, dan lain-lain.

\section{Media Sosial sebagai Produk Modernitas}

Tidak dapat disangkal bahwa media sosial (kelahiran, perkembangan, dan penggunaan) dapat dikenakan status penanda modernitas, artinya media sosial menjadi bagian tidak terpisahkan dari sejarah perkembangan grand narrative modernitas. Kalau didefinisikan maka modernitas tidak lain dari sebuah periode sejarah peradaban yang ditandai oleh industerialisasi, kapitalisme, negara-bangsa, pengawasan sosial semakin canggih (Barker, Chris, 2014: 178).

Dalam perspektif Marxisme modernitas dilihat sebagai proses inovasi kapitalis meliputi penguasaan alam dengan teknologi mesin. Mentalitas modern menjadikan jenis pekerjaan dibagi berdasarkan kelas, produktivitas didorong dengan sistem 
mekanisasi, dan dengan tujuan akhir dari semuanya adalah akumulasi kapital.

Dari perspektif filsafat, modernitas dapat dijelaskan sebagai kesadaran manusia atas kebaruan dan perkembangan hidupnya. Maka, tidak mengherankan kalau manusia baru disebut modern sejauh kekinian telah menjadi kesadarannya (Hardiman, 2004: 2-5). Modernitas adalah kesadaran manusia akan kebaruan, kekinian, dan perkembangan, tidak saja berkaitan dengan suatu lingkungan yang berubah, tetapi berkaitan dengan bagaimana manusia menyadari dirinya berada, menghidupi, dan berinteraksi dengan perkembangan yang terus berulang.

Penjelasan ini kurang lebih membantu kita menempatkan media sosial sebagai bagian dari sejarah (kesadaran) kekinian manusia. Secara ontologis media sosial selalu dihubungkan dengan media baru, atau media sosial dijelaskan dalam konteks media baru modern yang sedang berkembang. Karena itu kita sepakat dengan Lev Manovich (Robert Hasan \& Julia Thomas, 2006: 5-6) bahwa media baru (media sosial) selalu melibatkan penggunaan internet/komputer sebagai basis dasar memamerkan (tidak saja produk hasil ciptaannya), tetapi juga memamerkan dirinya sebagai sebuah eksistensinya dari adanya.

Sebagaimana modernitas sulit ditolak, media sosialpun sulit ditolak keberadaannya. Media sosial dalam pandangan filsafat modern, tidak sekadar alat, atau instrumen teknis manusia mengenal dunia, tetapi media sosial juga sudah menjadi dunia itu sendiri. Media sosial tidak lagi sekadar obyek yang dipakai, sebaliknya dia berubah menjadi subyek yang menentukan: cara berpikir, cara mengambil keputusan, cara manusia memahami, dan cara manusia membentuk dirinya secara digital.

Modernitas media sosial tidak lagi menjadi zona refleksi di mana manusia mengambil jarak kritis dengan dunia, tetapi dia menarik dunia menjadi dirinya. Keberadaan manusia diatur, bahkan dikontrol menurut cara kerja teknologi mekanistis dalam sebuah mesin gawai. Kalau Rene Descartes mengatakan "aku berpikir maka aku ada" sebagai ukuran eksistensi rasionalitas manusia modern, maka media sosial merubah prinsip rasional ini dengan prinsip lain, “aku merasa (kan), aku mengakrabi, bahkan aku menjadi dunia digital, maka aku ada”. Barangkali penjelasan tentang patologi media sosial yang akan dibahas kemudian bertolak dari argumentasi-argumentasi dasar ini.

\section{Media Sosial sebagai Media Informasi}

Kalau sekarang orang berbicara tentang era information surplus, era itu sebenarnya tidak lain dari era berkuasanya media sosial. Kegalauan manusia modern tidak saja karena kekurangan, atau ketinggalan informasi, tetapi sejajar dengan itu manusia modern juga mengalami kegalauan justeru karena informasi yang diterima terlalu banyak, bahkan berlebihan. Maka, tidak ada satu pun periode 
sejarah di mana manusia mengalami paradoks kegalauan, selain kegalauan yang diciptakan media sosial itu sendiri.

Manuel Castells (2009) menyebut fenomena ini sebagai mass selfcommunication, artinya media sosial berkepentingan untuk mengomunikasikan diri manusia kepada sebanyak mungkin orang (khalayak). Media sosial memungkinkan informasi yang banyak didistribusikan kepada banyak orang (from many to many) dan berlangsung, bisa dalam waktu yang cepat (real time) atau waktu yang bisa disesuaikan (Robert W. Vaagan, 2011: 18).

Sebagai media informasi di sinilah letaknya media sosial memiliki karakteristik yang khas dibandingkan dengan media-media mainstream. Perkembangan media sosial didorong oleh kekuatan teknologi baru yang memberi kesempatan kepada berlimpahlimpahnya informasi diterima khalayak. Informasi pun dengan mudahnya diperoleh lewat gawai, komputer, iPad, tablet mini, dan lain-lain.

Sebagai sebuah sistem yang mendesentralisasi siapa saja yang terlibat sebagai pengguna, media sosial berperan dalam mendistribusikan, memutuskan secara kolektif pesan yang diterima melalui sharingdan saran-saran yang diperlukan. Dalam cara berpikir sistem ini media sosial menempatkan partisipan tidak sekadar khalayak, tetapi juga sebagai publik yang
ISSN. 2527-8673

E-ISSN. 2615.6725

terhubung satu sama lainnya sebagai sebuah jaringan/networked public (Peter J Gill, 2012).

Media sosial dengan menggunakan infrastruktur internet sebagai basis operasionalnya telah menjadi sumber informasi utama dan diandalkan masyarakat modern. Masyarakat yang menempatkan kebebasan berekspresi sebagai hak dasar, maka media sosial dapat dimanfaatkan sebagai sumber informasi utama, terutama menyangkut: sharing gagasan dan pengetahuan; layanan jaringan sosial; menyeringkan beragam informasi secara interaktif; mengirim dan menerima/membaca pesan interaktif; melakukan diskusi dan berbagai perdebatan konstrutif lainnya (Ibid., Peter J Gill, 2012).

David Westerman $(2013,171)$ meyakini bahwa teknologi-teknologi komunikasi yang lebih baru meningkatkan berbagai kemungkinan bagaimana masyarakat dapat mengirimkan dan menerima banyak informasi. Mengutip S Fox, David Westerman (2013, 172) mengatakan bahwa masyarakat menggunakan media sosial, atau media online pada umumnya, terutama sebagai alat mengumpulkan sebanyak mungkin informasi, men-sharing-kan berbagai kisah, dan melakukan diskusi atas berbagai hal yang menjadi perhatian banyak orang. 
Patologi Media Sosial: Basis Kritik Filsafat

\section{Postmodern}

Secara amat tegas modernitas dicirikan oleh tiga kesadaran, yaitu subyektivitas, kritik, dan kemajuan (Hardiman, 2004: 3 - 5). Dengan subyektivitas berarti manusia menjadi ukuran untuk segala sesuatu. Dialah pusat yang menentukan dunia (dunianya, dunia orang lain, dan dunia lain). Manusia tidak saja menjadi subyek, dia juga menyejarah (hidup dalam sejarah dan menentukan sejarah). Karenanya modernitas dicirikan oleh perkembangan, bahwa manusia hidup dalam waktu, memberi arti, dan merancang waktu progresif untuk hidupnya.

Manusia modern yang menyejarah tidak begitu saja merasa nyaman dengan status quo sebagai sebuah stabilitas, maka manusia modern selalu memberontak melawan status quo tradisi dan moralitas stabil tersebut. Untuk membebaskan diri dari stabilitas tradisi dan moralitas manusia modern mengambil jalan kritik rasional untuk memberi posisi baru kesadarannya.

Sebagai anak kandung modernitas media sosial mengadopsi cara kerja modernitas untuk menggambarkan eksistensinya. Kerric Harvey (2014: xxxiv-xxxv), menyebut beberapa karakteristik dasar media sosial, antara lain: Diorganisasikan teknologi; Media sosial merupakan gambaran diri meskipun pengguna tidak menyadarinya; Media sosial berkembang secara organik.
Dari aspek pesan, media sosial menyampaikan pesan dengan format pendek, langsung, kadang-kadang ekstrim menyerang pribadi; Media sosial mendorong sebuah model/konteks komunikasi yang sering tidak memakai aturan berbahasa yang biasa; Media sosial sering muncul dalam berbagai permainan politik meskipun tidak disadari politisi; Media sosial sering mengeksploitasi sensitivitas emosi masyarakat; Media sosial secara spontan menghadirkan hal-hal yang instan, termasuk juga ekspresi keyakinan, pendapat, pengamatan, dan pengalaman; dan Media sosial mengutamakan unsur rekreatif dari sebuah peristiwa.

Paul Levinson, dalam Paul Messaris (2007: 122-126) mengatakan bahwa era seluler memang dapat disebut sebagai sebuah era keemasan. Era dimana muncul kebohongan putih. Dengan telepon seluler memberikan nomor telepon kita, sekaligus memberikan diri kita kepada orang lain kapan saja dan dimana saja. Munculnya panggilan tak tertahankan. Bunyi telepon seluler menuntut orang memberi perhatian di atas segala hal. Makan malam, percakapan keluarga, dan bahkan even bercinta dirusak oleh panggilan telepon (telephonus interruptus).

Menurut Paul Levinson, adanya fenomena rayuan teks bisu. Percakapan di telepon seluler lewat cuplikan tulisan tidak bisa dihindari, dan manfaatnya besar. Namun, bunyi tanpa identitas akan menimbulkan kegaduhan. Teks juga memiliki sisi gelap 
dalam menghadapi telepon seluler. Teks boleh saja secara sosial menggangu individu, tetapi unggulnya dia menghubungkan kita pada orang lain, namun sinar seluler adalah hal lain yang mestinya menjadi perhatian.

Di satu sisi, karakteristik-karakteristik ini menggambarkan kepenuhan eksistensi media sosial dalam format modernitas, namun di sisi lain inilah saatnya hidup manusia "enslaved by digital technology" (Roberto Simanowski: 2016: 184-205). Perbudakan teknologi digital yang berlangsung secara sistematis atas kemanusiaan itulah yang disebut sebagai patologi etis media sosial dilihat dari format postmodernisme.

Apa sesungguhnya sebuah patologi? Secara ensiklopedis, arti kata patologi dapat ditelusuri pemaknaannya dari Kamus Besar Bahasa Indonesia (2008: 1031) sebagai ilmu tentang penyakit. Penggunaan terminologi patologi dapat diterapkan dalam empat konteks, yaitu konteks bahasa, konteks forensik, konteks lingkungan, dan konteks sosial.

Dalam konteks bahasa patologi dijelaskan sebagai penyelidikan mengenai cacat dan gangguan yang menghambat kemampuan berkomunikasi verbal orang. Dari konteks forensik patologi dijelaskan sebagai penerapan ilmu dan metode patologi untuk menyelesaikan masalah peradilan. Dalam konteks lingkungan patologi dijelaskan menyangkut persoalan yang berkaitan dengan lingkungan kehidupan manusia. Dan, dari konteks sosial patologis dimaknai sebagai ilmu yang secara khusus mempelajari tentang penyakit masyarakat.

Dalam tradisi pemikiran kritis mazhab Frankfurt, Axel Honneth (1949 - ), seorang kritikus sosial dari generasi ketiga mazhab menggunakan terminologi patologi untuk mengoreksi cara berpikir generasi pertama dan kedua mazhab Frankfurt. Generasi pertama diwakili oleh Theodor W. Adorno, Max Horkheimer dan Herbert Marcuse dan generasi kedua diwakili Jurgen Habermas. Menurut Axel Honneth, baik generasi pertama maupun kedua mazhab Frankfurt mengandung patologi dalam klaim rasionalitasnya.

Menurut Honneth, ada sebuah rasio universal yang menyediakan berbagai kemungkinan terealisasinya aktualisasi diri subjek, namun terbedakan oleh asal usul karakter tindakan praktisnya. Karena itu, ketika Horkheimer mereduksi segala kemungkinan dengan tindakan kerja, atau, ketika Herbert Marcuse berbicara tentang kehidupan estetis, dan juga ketika Habermas mereduksi segala hal kepada konsensus komunikatif sebagai prasyarat integrasi sosial, maka pada ketika yang sama sebenarnya telah terjadi patologi sosial, atau proses defisit atas rasionalitas (Honnet, 2009: 27-31).

Bagaimana konsep patologi diterapkan untuk memahami fenomena media sosial dalam perspektif cara berpikir filsafat postmodernisme? Dan, bagaimana meletakan 
media sosial dalam konteks kekinian masyarakat kontemporer?

Kita tahu bahwa tesis dasar postmodernisme adalah matinya narasi besar modernitas (Lyotard, dalam Victor E. Taylor \& Charles E. Winquist, 2001: 234-235) karena kelahiran narasi-narasi kecil yang bersifat lokal; hancurnya moralitas universal obyektif karena keyakinan akan kekuatan pluralitas konteks sosial masyarakat; atau, rasionalitas modern tidak cukup energi untuk menolak berbagai mitologi tradisional karena manusia tidak mungkin hidup tanpa tradisi; atau, kesadaran rasional modernitas tidak cukup menjelaskan eksistensi totalitas manusia, karena Sigmund Freud (1856-1939) berhasil membongkar berbagai dimensi ketaksadaran dalam klaim kesadaran rasional tersebut.

Dengan demikian kesadaran modernitas mengandung patologi etis dalam dirinya. Dan, patologi etis modernitas akan berimbas kepada patologi media sosial sebagai anak kandungnya. Patologi media sosial menyatakan diri lewat karakteristikkarakteristik yang sudah dibahas di atas.

Di sini, perlu ditegaskan bahwa kehadiran postmodernisme, tidak berambisi mengganti cara berpikir linier modernitas, tetapi dia menawarkan cara berpikir siklis bahwa sejarah akan terus berputar mengikuti irama dari konteks pluralitas sosial masyarakatnya.

Perkembangan media sosial sebagai penanda modernitas tidak selalu beroposisi dengan berbagai pertimbangan etis, tetapi selalu bergerak bersama untuk membangun peradaban yang konstruktif. Kalau demikian halnya, bagaimana mengatasi patologi tersebut?

Patologi media sosial hanya bisa diatasi dengan cara membangun infrastruktur postmodernisme yang memberi peluang bagi beroperasinya nilai dan prinsip-prinsip etika. Secara sederhana etika memiliki beberapa prinsip moral dasar: (1) sikap baik; (2) tidak melakukan kejahatan; (3) melakukan yang baik; (4) berlaku adil; dan, (5) prinsip menghormati kebebasan memilih dan menentukan diri secara otonom (Sudarminta, 2013: 70-75).

Etika memiliki nilai praksis moral yang bersifat universal, baik dalam pengertian umum sebagai syarat yang dipenuhi agar manusia dianggap baik dari sudut moral, maupun dalam pengertian khusus yang mengaitkan nilai etika kepada peristiwaperistiwa, atau fakta-fakta khusus norma yang bisa diterapkan pada bidang-bidang spesifik (Bertens, 2013: 15-16).

Etika, baik pada level ilmu yang merefleksikan masalah-masalah moral secara kritis dan argumentatif maupun sebagai pedoman berperilaku praktis menuntut setiap orang bertindak menurut standar-standar norma yang berlaku umum. Dengan demikian keberlakuan etika mengatasi ruang dan waktu, termasuk ruang dan waktu dari siklus 
perubahan dalam masyarakat modern dewasa ini.

Postmodernisme memberi ruang keterbukaan bagi etika untuk memasuki perubahan cara dan gaya manusia memanfaatkan media, termasuk media sosial. Bertolak dari prinsip-prinsip dan nilai-nilai etis ini media, termasuk media sosial dituntut untuk: melindungi privasi setiap orang; menjamin akurasi informasi; melindungi hak asasi setiap orang; menjamin setiap orang untuk mengakses berbagai sumber daya yang tersedia; dan kebebasan berekspresi harus selalu mempertimbangkan pluralitas sosial dengan berbagai narasi kecil yang menyertainya (Robert W. Vaagan, 2001: 1921).

Dengan kata lain, format postmodernisme menuntut media sosial mendasarkan diri pada prinsip-prinsip dan nilai-nilai etika normatif. Pada saat kita menggunakan media sosial, apa pun bentuknya, ingat: bahwa asosiasi dan partner komunikasi kita sedang menggunakan media sosial yang sama; lawan, atau bahkan musuh kita sedang menggunakan media sosial; pelanggan, sabahat, keluarga kita sedang menggunakan media sosial; tetapi kita harus menyadari bahwa mereka menuntut kita untuk menggunakannya juga (Discovery University, 2011).

Bertolak dari tesis dasar postmodenisme dan norma yang berkembang dalam masyarakat modern, etika relevan untuk dibicarakan dalam beberapa konteks: (1) Melakukan refleksi kritis atas perubahan yang terjadi, termasuk perubahan dan perkembangan teknologi komunikasi media yang sebelumnya tidak diprediksikan; (2) Membantu manusia menemukan orientasi hidup dan mempertanggungjawabkan pilihan dan tindakan secara rasional dan bertanggungjawab; (3) Secara instrumental etika menjadi pisau analisis untuk menanggapi munculnya masalah moral baru yang diakibatkan oleh proses modernisasi yang begitu cepat (Sudarminta, 2013: 10-11).

\section{PENUTUP}

Media sosial (Facebook, Instagram, Twitter, Youtube, Wikipedia, MySpace, Blogs, dan lain-lain), dengan segala perkembangannya tidak bisa dihindari. Secara ontologi keberadaannya dituntut dan dituntun oleh sejarah dan memang harus ada dan memengaruhi seluruh aspek kehidupan manusia. Dia, tidak saja memberi kemudahan tetapi juga mendatangkan masalah bagi kehidupan manusia, terutama kalau kita tidak mengelolanya dengan baik.

Perspektif epistemologis memberi jalan supaya kita mengetahui hakekat media sosial dan bagaimana cara menggunakannya supaya kebermanfaatannya sungguh-sungguh hakiki. Kenyataan yang tidak bisa disangkal bahwa media sosial adalah anak kandung modernitas dengan segala klaim rasionalitas yang menyertainya. Tesis dasar modernitas yang 
mendudukan otonomi diri dalam kebebasan berekspresi bisa menjadi bumerang bagi dirinya.

Postmodernisme menjadi yang terdepan melawan cara berpikir linier modernitas dengan menawarkan cara berpikir berbasis siklus yang terus berulang. Cara berpikir postmodernisme, berhasil menelanjangi berbagai kontradiksi pemikiran modernitas (grand narratives), lewat berbagai implikasi kerusakan yang dibawanya. Kesadaran subyek pada pemikiran modern mengalami kiamat total ketika kesadaran rasional tersebut tidak menyadari dirinya sedang dikuasainya oleh berbagai dimensi ketaksadaran (Sigmund Freud) untuk mencapai kepenuhannnya.

Media sosial yang mengikuti cara kerja modernitas sedang diinggapi patologi etis, tidak saja dalam adanya, tetapi juga dalam cara kerjanya secara riil. Postmodernisme tidak percaya dengan cara kerja obyektif rasional universal modernitas karena terbukti media sosial tidak sepenuhnya menjanjikan perkembangan positif kepada masyarakat, tetapi sebaliknya kerusakan-kerusakan sosial. Postmodernisme menawarkan cara kerja regresi, yaitu kembali kepada etika tradisional apa adanya.

Patologi etis media sosial hanya bisa diatasi sejauh nilai-nilai dan prinsip-prinsip etika diletakkan secara proporsional dalam menghadapi rasionalitas perkembangan teknologi baru dalam bidang komunikasi di era modern. Postmodernisme tidak percaya media sosial sebagai grand narratives, berhasil mengatasi berbagai persoalan yang dihadapi manusia, tetapi postmodernisme menyakini bahwa penerimaan/pengakuan atas little narratives dalam pluralitas konteks sosial budaya dapat menyelamatkan media sosial dari patologi etis sejarah yang sengaja dikandung sejak kelahirannya.

\section{REFERENSI}

Barker, Chris. (2014). Kamus Kajian Budaya (terj. B. Hendar Putranto). Kanisius: Yogyakarta.

Bertens. K. (2013). Etika (Edisi Revisi). Kanisius: Yogyakarta.

Castells, Manuel. (2009). Communication Power. Oxford University Press.

Creswell, John W. (2010). Research Design: Pendekatan Kualitatif, Kuantitatif, dan Mixed (terj. Achmad Fawaid). Pustaka Pelajar: Yogyakarta.

Discovery University, (2011). The Ethics of Social Media. Comperire Verum.

Gill, Peter J. (2012). "Why should I Use Social Media?" Makalah Seminar. University of Oxford: England.

Given, M. Lisa (ed.). (2008). Encyclopedia of Qualitative Research Methods (Vol 1 \& 2). Sage Publication: Los Angeles.

Hasan, Robert \& Julia Thomas. (2006). The New Media Theory Reader. McGrawHill: New York. 
Hardiman, F. Budi. (2004). Filsafat Modern, dari Machiavelli sampai Nietzsche. Gramedia: Jakarta.

Hicks, Stephen R.C. (2014). Explaining Postmodernism: $\quad$ Skepticism and Socialism from Rousseau to Foucault. Ockham Razor Publishing.

Honneth, Axel. (2009). Patologies of Reason: on the Legacy of Critical Theory (terj. James Ingram). Columbia University: New York.

Kerrik, Harvey. (2014). Encyclopedia ofSocial Media and Politics. Sage Publication: London.

Liliweri, Alo. (2018). Paradigma Penelitian Ilmu Sosial. Pustaka Pelajar: Yogyakarta.

Looy, Amy Van. (2016). Social Media Management: Technologies and Strategies for Creating Business Value: New York: Springer: New York.

Messaris, Paul \& Lee Humphreys. (2007). Media Digital: Transformations in Human Communication. Peter Lang Publishing: New York.

Mulyana, Deddy. (2013). Metode Penelitian Kualitatif, Paradigma Baru Ilmu Komunikasi dan Ilmu Sosial lainnya. Rosda Karya: Bandung.

North, Malcolm. (2013). "Realizing A Vision for Global Value Education”. Dalam Journal of Formal Axiology: Theory and Practice (Vol.6). Robert S Hartman Institute: Athena.
ISSN. 2527-8673

E-ISSN. 2615.6725

Simanowski, Roberto. (2016). Digital Humanities and Digital Media. Open Humanities Press: Lodon.

Sudarminta, J. (2013). Etika Umum: Kajian tentang Beberapa Masalah Pokok dan Teori Etika Normatif. Kanisius: Yogyakarta.

Taylor, Victor E \& Charles E. Winquist (ed.) (2001). Encyclopedia of Postmodernism. Routledge: LOndon.

Vaagan, Robert W. (2011). "Ethics, Social Media and Mass Self-Communication”. Library and Information Science. Oslo University College: Norway. 